\title{
44. PRELIMINARY PALEOMAGNETIC CHRONOLOGY OF CENOZOIC SEDIMENTS FROM DSDP SITES 372, 374, AND 376 OF THE MEDITERRANEAN SEA
}

\author{
Norman Hamilton and Ernest A. Hailwood, University of Southampton, United Kingdom \\ and \\ Robert B. Kidd, Institute of Oceanographic Sciences, Wormley, Surrey, United Kingdom
}

\begin{abstract}
Preliminary paleomagnetic investigations are reported on some 100 samples taken from sediment cores recovered at DSDP Sites 372, 374, and 376 of the Mediterranean Sea. Tentative attempts are made to correlate the observed magnetic polarity sequences at these sites with an established geomagnetic polarity time scale. Constraints afforded by detailed biostratigraphic zonations available for the sediments allow the reliability of such paleomagnetic correlations to be assessed.
\end{abstract}

\section{INTRODUCTION}

Increasing use is being made of paleomagnetic data in calibrating the Cenozoic biostratigraphic zonations. Already Ryan et al. (1974) have produced a paleomagnetic assignment of Neogene stage boundaries that is being widely used, and recently Tarling and Mitchell (1976) have described some revised estimates based on isotopic ages for the entire Cenozoic polarity sequence. These calibrations enable paleomagnetic data obtained from other sedimentary sequences to be used for correlation purposes and for both refinement of biostratigraphic dating and absolute dating in those intervals barren of zonal fossils. There exist some essential prerequisites which should be satisfied if sediments are to be used in this manner for refining or developing a magnetic polarity stratigraphy. Amongst these are included possession of a stable primary magnetization acquired at or soon after deposition and absence of deformation. The relevance of these and other aspects, such as sampling frequency, have been reviewed by Hailwood (in press).

Most of the paleomagnetic study reported here has concentrated on samples taken from post-evaporitic sediments, Quaternary and Neogene in age, cored at three widely separated sites, 372,374 , and 376 , during Leg $42 \mathrm{~A}$ in the Mediterranean Sea (Figure 1). A limited analysis of some pre-evaporite middle Miocene sediments from Site 372 is included also. Unfortunately, it was not possible to achieve continuous Neogene-Quaternary sampling at one site alone.

In order to use reliable data from such nannofossil oozes and marls which make up much of this part of the stratigraphic succession, considerable care is necessary in selection of sampling points so that horizons showing any disturbance by drilling or by post-depositional processes such as slumping are avoided. To this end, all the samples reported here were carefully selected by a shipboard sedimentologist (RBK). Samples from above an in-hole depth of about 50 meters were invariably unusable. In this paper we concentrate particularly on some critical parts of the stratigraphic record.

\section{MEASUREMENT PROCEDURE}

All samples are oriented vertically, but lack absolute azimuthal orientations. The paleomagnetic measurements were completed using a Digico Digital Spinner Magnetometer System. The principles of operation of this system have been described by Molyneux (1971), and the measuring technique employed with DSDP sediment reported by Hamilton (1974).

For these samples a triplicate measurement was made of the natural remanent magnetization (NRM). The precision of an individual mean result was then assessed by using the circular standard deviation (CSD $=81 / \mathrm{k}$ ) where $k$ is the Fisher precision parameter (Fisher, 1953), calculated from the triplicate measurement. Following preliminary investigation of the NRM, pilot samples were subject to alternating field demagnetization up to 300 oe. In the light of previous experience, it was felt that in order to assess stability characteristics and seek a stable inclination value, every sample should ideally be subject to step-wise pilot demagnetization. Unfortunately constraints on time prevented us from achieving this for the entire sample population. However, this was done for all samples from Site 376 and a majority from Site 372 . For samples from Site 374, pilot demagnetizations were completed on the basis of one sample per barrel and additional further pilot demagnetization on those critically placed samples that occur near reversed polarity boundaries.

Figure 2 illustrates examples of the behavior during progressive demagnetization of some selected samples from Site 376. Several different types of behavior are 


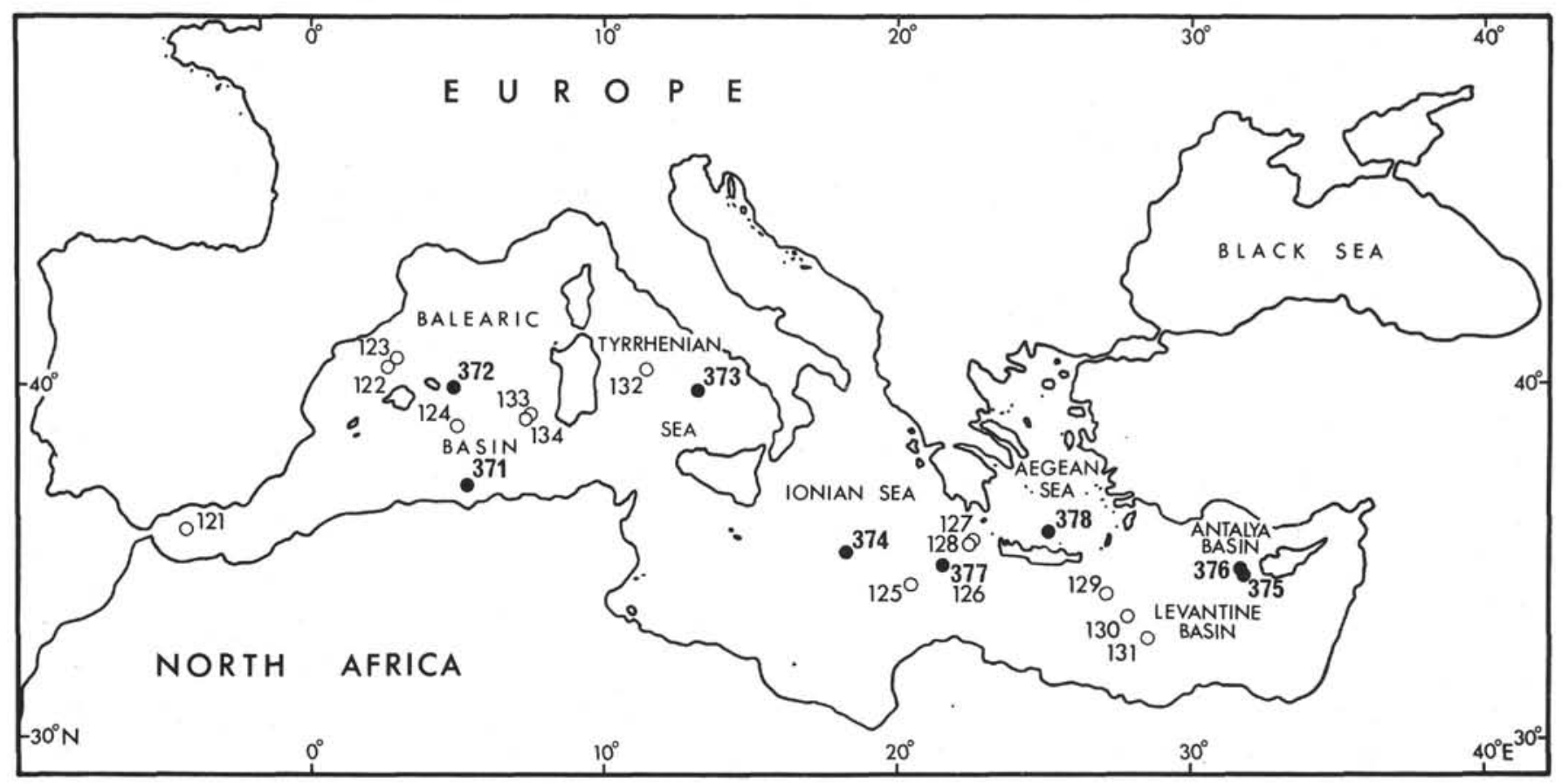

Figure 1. Locations of Leg $42 \mathrm{~A}$ sampling sites in relation to those of Leg 13.

indicated by the samples shown in the figure. Some samples are highly stable up to the peak demagnetizing value of 300 oe (Samples 7-1, 136-138 and 12-1, 37-39). Others change from normal to reversed polarity (e.g., Sample 12-1, 124-126), while others show a clear progressive change in direction having not reached a terminal direction by the time the higher demagnetizing field is employed (Samples 7-2, 27-29 $\mathrm{cm}$ and $10-2,25-27 \mathrm{~cm}$ ). These qualitative appraisals of behavior during demagnetization allow us to have some confidence in the reliability of the sample inclinations given in the results summary tables. Subsequent discussion of the magnetic stratigraphy is based on the demagnetized data.

\section{DISCUSSION OF RESULTS}

\section{Site 372}

Paleomagnetic sampling at Site 372 in the western Mediterranean basin on the East Menorca Rise provided four samples from Core 4 (immediately above the Messinian evaporites) and a sequence of samples from the pre-evaporitic nannofossil marls of upper middle Miocene age. The results are summarized in Table 1.

A polarity change from reversed to normal occurs in Core 4 at a depth of approximately 151 meters, which is preceded immediately by a change from normal to reversed polarity, thus defining a very thin (less than $50 \mathrm{~cm}$ ) normal zone.

This sequence is located almost immediately above the gypsum and gypsiferous dolomitic marl that is first encountered in Core 5. We can interpret the magnetic stratigraphy here as correlating with the Epoch 5/Gilbert boundary (Miocene/Pliocene boundary). The evaporites then lie below a reversed sequence. Whether this is the reversal of Epoch 5 at 5.5 m.y. is not resolved by our data at this site, however, information from Site 374 is pertinent to this (see later).

The pre-evaporitic samples studied paleomagnetically commencing with Core 9 and continuing through Cores $10,11,12$, and 13 provided some interesting polarity information when viewed against the background of the paleontological zonations for these cores. Apart from one sample, 10-2, 122-124 cm, the sequence between 199 and 230 meters depth is dominated by negative inclinations, whereas all the Core 13 samples have positive inclinations and the lowermost sample from Core 19 is also positive. A very tentative attempt to assign these results using the indicated polarities to their position in the geomagnetic time scale is illustrated in Figure 3. This assignment suggests that the sequence between 200 and 300 meters at Site 372 ranges in absolute age between 12 and 16 m.y.B.P. The polarity data appears therefore to confirm an approximate age range of 11 or 13 to 13 or 15 m.y.B.P. given by accepted age ranges of the biostratigraphic zonation.

Core 9, Section 2, is a subject of some critical interpretation (see elsewhere in this volume, including Site 372 summary chapter), as an unconformity may be present here with Messinian sediments directly overlying Serravallian strata. Here, an alternative explanation has been advanced (Bizon, Chapter 3 ) that the unconformity lies above the top of Core 9 and represents a reduced time span in that some Tortonian strata are preserved below the unconformity. The boundary between planktonic foraminiferal zones (N16/N15) has been located by Bizon at Sample 9-2, $110 \mathrm{~cm}$. A reference to the calibrated palaeomagnetic time scale of Ryan et al. (1974) indicates that this boundary occurs within the lower reversed interval of 

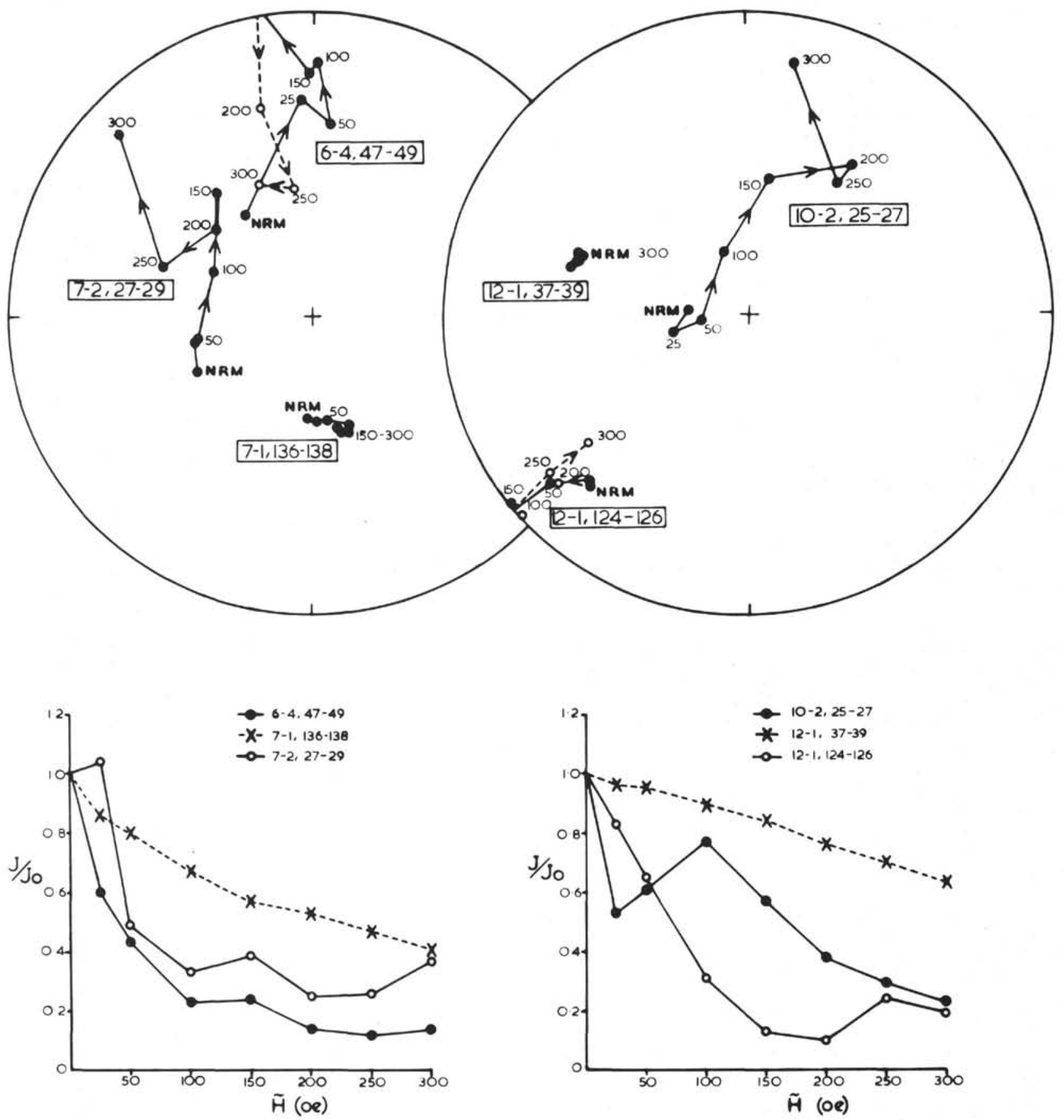

Figure 2. Behavior of some typical samples from Site 376 during progressive alternating field demagnetization. Data plotted on polar stereographic projection, with arbitrary declination for each sample: lower part of figure illustrates associated intensity decay curves.

Epoch 10, dated tentatively ca.11 m.y. The palaeomagnetic data described here may be seen as supporting this alternative interpretation if the reversed zone at 200 meters is assigned to the lower reversed interval of Epoch 10 rather than the upper reversed interval of Epoch 12, as shown in Figure 3. Unfortunately our data is limited by the lack of adequate sampling coverage so that we cannot resolve which of these two alternative interpretations are most likely to be correct.

Clearly further refinement of these time scales is necessary, coupled with more detailed palaeomagnetic investigation of the lower part of this stratigraphic interval at this site.

\section{Site 374}

This site, located to the south of the Mediterranean Ridge on the Ionian abyssal plain, sampled a stratigraphic interval from Quaternary through to the Messinian evaporite sequence. Paleomagnetic study has been concentrated in the depth interval from 157 meters (Sample 2-1, 84-86 cm) to 392 meters subbottom depth (Sample 13-3, 140-142 cm), the latter being 
TABLE 1

Summary of Paleomagnetic Data, Site 372

\begin{tabular}{|c|c|c|c|c|c|c|c|c|c|c|}
\hline \multirow[b]{2}{*}{$\begin{array}{l}\text { Sample (In- } \\
\text { terval in } \mathrm{cm} \text { ) }\end{array}$} & \multirow{2}{*}{$\begin{array}{l}\text { Depth } \\
\text { in hole } \\
\text { (m) }\end{array}$} & \multicolumn{4}{|c|}{ N R M } & \multicolumn{5}{|c|}{ After AF Demagnetization } \\
\hline & & DEC & INC & CSD & $\begin{array}{c}\mathrm{INT} \pm \mathrm{SD} \\
(\mu \mathrm{G})\end{array}$ & $\begin{array}{l}\text { Field } \\
\text { (oe) }\end{array}$ & DEC & INC & $\operatorname{CSD}^{\mathrm{a}}$ & $\begin{array}{l}\text { INT } \\
(\mu \mathrm{G})\end{array}$ \\
\hline $4-1,74-76$ & 150.75 & 345.0 & -62.5 & 5.7 & $0.48 \pm 0.07$ & 200 & 289.8 & -40.1 & $(3.1)$ & 0.43 \\
\hline $4-1,100-102$ & 151.01 & 97.3 & +72.8 & 1.0 & $20.91 \pm 0.38$ & 300 & 23.2 & +15.0 & (3.3) & 3.40 \\
\hline $4-1,124-126$ & 151.25 & 139.6 & -1.5 & 0.7 & $5.77 \pm 0.12$ & 300 & 132.5 & -4.4 & $(0.7)$ & 1.79 \\
\hline $9-2,36-37$ & 199.36 & 117.6 & -4.6 & 1.6 & $8.26 \pm 0.30$ & 300 & 117.4 & -2.9 & $(1.7)$ & 6.45 \\
\hline $9-2,87-89$ & 199.88 & 151.6 & -16.7 & 1.7 & $12.72 \pm 0.41$ & 300 & 155.2 & -18.9 & $(1.2)$ & 8.85 \\
\hline $9-3,110-112$ & 201.61 & 107.6 & -34.1 & 0.9 & $3.43 \pm 0.05$ & 300 & 109.7 & -33.3 & $(1.2)$ & 2.08 \\
\hline $9-4,78-80$ & 202.79 & 289.7 & +15.3 & 1.6 & $2.79 \pm 0.02$ & 250 & 304.4 & -3.4 & $(2.0)$ & 1.83 \\
\hline $10-2,112-114$ & 209.73 & 191.4 & +14.1 & 5.2 & $0.29 \pm 0.02$ & 150 & 202.5 & +1.4 & (3.4) & 0.14 \\
\hline $11-2,70-72$ & 218.71 & 5.5 & -60.2 & 3.4 & $0.27 \pm 0.02$ & 150 & 221.0 & -66.4 & $(7.9)$ & 0.10 \\
\hline $12-3,100-102$ & 230.01 & 335.2 & -24.4 & 3.0 & $0.12 \pm 0.00$ & 60 & 347.9 & -12.8 & 23.7 & 0.05 \\
\hline $13-3,21-22$ & 238.71 & 48.6 & +30.3 & 3.5 & $0.61 \pm 0.05$ & 300 & 135.6 & +36.3 & $(7.9)$ & 0.04 \\
\hline $13-4,140-142$ & 241.41 & 290.0 & +54.5 & 17.4 & $0.18 \pm 0.09$ & 50 & 305.0 & +24.6 & 43.9 & 0.11 \\
\hline $13-5,110-110$ & 242.61 & 90.8 & +57.7 & 46.0 & $0.04 \pm 0.01$ & 50 & 180.6 & +77.6 & 55.9 & 0.04 \\
\hline $19-6,90-92$ & 300.91 & 270.0 & +55.3 & 30.6 & $0.08 \pm 0.03$ & 50 & 251.3 & +51.8 & 15.4 & 0.15 \\
\hline
\end{tabular}

${ }^{\mathrm{a}} \mathrm{CSD}$ based on 50 oe value.

located in the dolomitic marl (lithologic Unit 4A) which overlies the crystalline and laminated gypsum of the lower part of the cored interval. There is considerable interest in the recognition of the Miocene/Pliocene boundary within this sequence; previous workers have located this at or within the upper part of Epoch 5, (Cita, 1975). Unfortunately as the hole was not continuously cored throughout, the paleomagnetic sampling is not as complete as would be desirable, making correlations with the established Neogene polarity time scale somewhat problematical. Biozonations recognized at this site, using foraminifers and nannofossils, provide useful constraints on any suggested correlations.

Some 50 samples were studied paleomagnetically from this site-and the results are reported in Table 2. The NRM intensities show a range from $5.5 \times 10^{-5} \mathrm{G}$ down to $6 \times 10^{-8} \mathrm{G}$. Although there is some variability in downhole magnetic intensity generally, there is a trend towards lower intensities in the interval immediately overlying the evaporites. The higher intensity values occur within the Quaternary and upper Pliocene part of the stratigraphic section, reflecting a higher terrigenous input.

At first glance the results show a dominance of positive inclinations indicative of normal polarity. As such, Site 374 shows some similarities with the earlier observations of Ryan (1973) at the Tyrrhenian Sea (Site 132) and Ionian Basin (Site 125) sites which were also characterized by a preponderance of normal polarities. For Site 374, there are some instances of well-defined negative inclinations, for example in Core 5 and again in Cores 12 and 13. The biostratigraphic zonation for this site indicates that the Quaternary/ Pliocene boundary occurs at a subbottom depth of about 300 meters, i.e., within Core 5. This would appear to correlate reasonably well with the interval of normal polarity observed in Core 5 , Section 3 , and Core 5, Section 4. If this can be identified as the Olduvai event, then it provides a good anchor point on which to examine both the preceding and succeeding polarities.
It seems somewhat anomalous that the first reversal of polarity encountered downhole occurs only in Sample $5-2,12-14 \mathrm{~cm}$ (subbottom depth of $298 \mathrm{~m}$ ), the overlying interval between 157 and 257 meters apparently having entirely normal polarity. It must be noted, however, that two 40-meter unsampled intervals intervene here, so that the paleomagnetic results must be viewed with some caution. Nevertheless, one possible interpretation of this is that this normal polarity sequence is still within the Brunhes Epoch and the Brunhes/Matuyama boundary is located between 257 and 298 meters in depth. This would necessitate a sedimentation rate of the order of $400 \mathrm{~m} / \mathrm{m}$.y. which is considerably greater than the sedimentation rate of 154 $\mathrm{m} / \mathrm{m}$.y. at this site inferred from the biostratigraphic evidence. We speculate that overprinting during the Brunhes normal epoch may have occurred here and affected much of the sediment column within the Quaternary, obscuring the reversed polarities of the Matuyama Epoch.

Below the supposed Olduvai event a sequence of normal polarity occurs throughout the sampled interval between 330 and 363 meters depth. However, the continuity of this is broken by a series of thin intervals which were unsampled. The planktonic foraminiferal zonation places the upper Pliocene/lower Pliocene boundary within this sequence at about 348 meters. As the base of the upper Pliocene has normally been taken to coincide with the Gauss/Gilbert boundary, this would suggest that the interval sampled paleomagnetically between 330 meters and this depth is likely to represent much of the Gauss Epoch. Normal polarities observed here confirm this inference. Although again it seems that the short reversed events, the Mammoth and the Kaena events, are undetected. Below 349 meters normal polarities are present to 363 meters. These must correspond to a normal interval (or intervals) within the Gilbert Epoch. Their closeness to the upper Pliocene/lower Pliocene boundary requires some comment in that the reversed interval dated between 3.32 m.y. and 3.79 m.y. (Tarling and Mitchell, 1976) is 


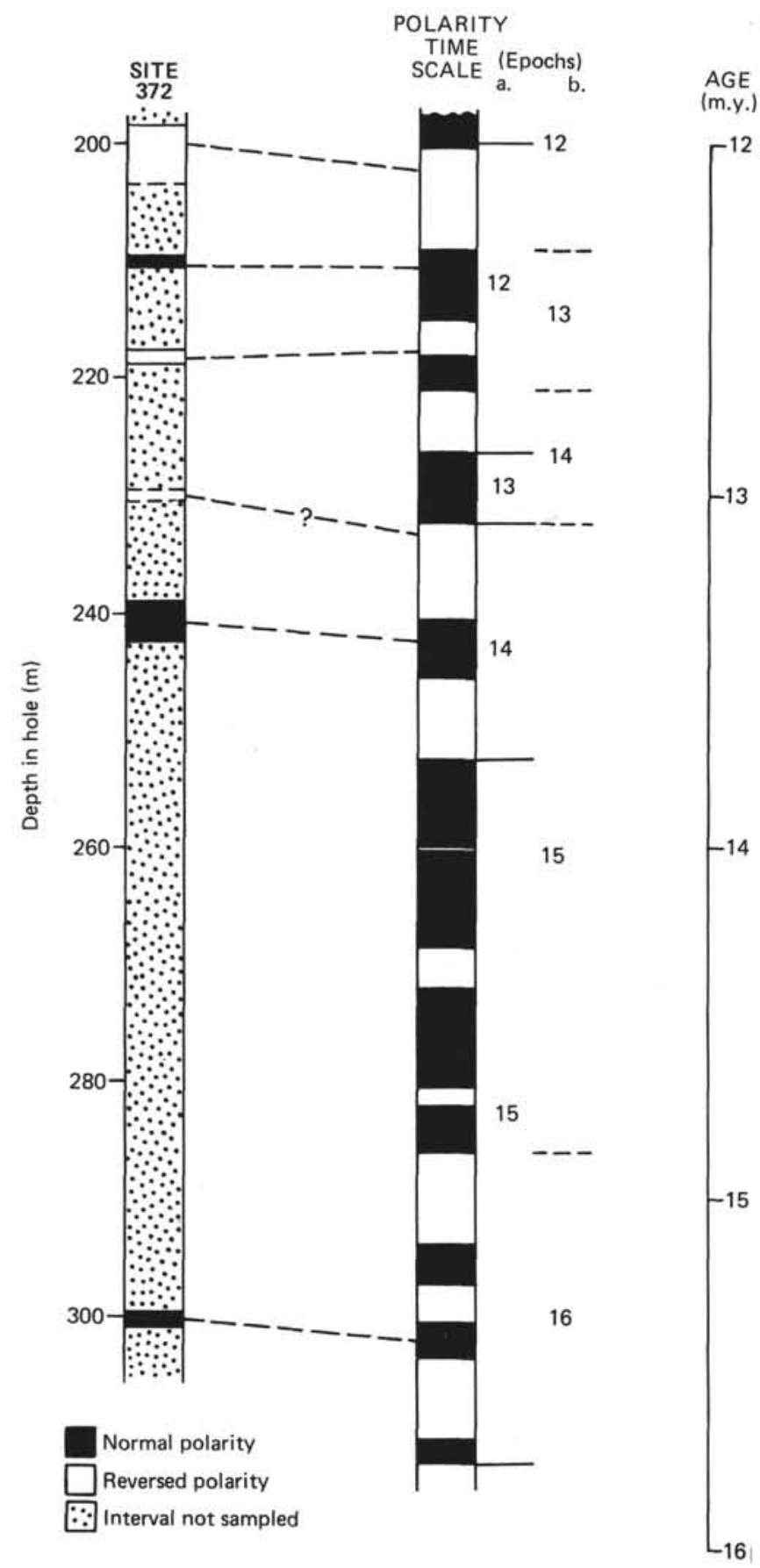

Figure 3. Observed down-hole polarity changes within the pre-evaporitic interval between 200 and 300 meters depth at Site 372 compared with the established geomagnetic polarity time scale (Tarling and Mitchell, 1976). Tentative correlations are inferred assuming a linear sedimentation rate of approximately $15 \mathrm{~m} / \mathrm{m} . \mathrm{y}$. Magnetic epochs taken from (a) Ryan et al. (1974) and (b) Tarling and Mitchell (1976).

not detected and must be either thin or absent at this site. This concurs with the observation of a low sedimentation rate in this interval deduced from the foraminifer zonation. Recognition of which of the four normal events in the Gilbert Epoch are represented here cannot be resolved.
The results in Table 2 show a reversed to normal boundary at 383 meters depth which is within 1 meter of the Miocene/Pliocene boundary determined biostratigraphically. This is in agreement with earlier observations that Epoch 5/Gilbert Epoch boundary is located close to or at the Miocene/Pliocene boundary. The normal interval below 383 meters contains a single reversed sample (Sample 12-2, 36-38.5 cm). Samples on either side of this show intermediate positive inclinations so that we have some confidence that we may have detected a short duration reversed event. A further reversal occurs at 390 meters depth. This situation has some similarity to that observed at the upper Pliocene/Miocene boundary for Site 372. The evidence from these two Mediterranean sites is that there could be one, possibly two, short reversed events within the normal interval of Epoch 5 above the principal reversed event that has been dated at approximately 5.5 m.y.

\section{Site 376}

Site 376 located west of Cyprus at the foot of the Florence Rise was continuously cored and offers potentially a useful succession for paleomagnetic study. Unfortunately the Quaternary nannofossil marls were subject to considerable drilling disturbance rendering them unsuitable for paleomagnetic investigation. Underlying Pliocene sediments are less disturbed but the occurrence of a slumped unit of early Pliocene age complicates the stratigraphic succession. For these reasons sampling for paleomagnetic study has been concentrated mainly in a 63-meter interval within the post-evaporitic succession of marlstones and interbedded turbidite sandstones and siltstones, Cores 7 through 13. Additionally, three samples were taken from Core 6, Section 4, which is a complicated succession of lower and upper Pliocene marls. The samples come from a part of the section which has been assigned to the MPl-1 zone (early Pliocene). Consistent reversed polarities observed for this section are in accordance with a biostratigraphic age of early Pliocene as this corresponds to the lowermost reversed interval of the Gilbert Epoch.

The summary of paleomagnetic results contained in Table 3 indicates an interesting diversity of data whose NRM intensities range over three orders of magnitude, with an unusual predominance of negative inclinations after demagnetization. The post evaporitic sequence displays eight, possibly nine, reversed polarity intervals separated by thin normal zones. Assignment of such a sequence to the established polarity time scale is crucial in the context of this site as this sedimentary succession contained few autochthonous microfossils making biozonation difficult.

On the assumption of continuous sedimentation, although at slightly varying rates of accumulation, it is possible to correlate tentatively the observed polarity sequence to that interval of the established time scale between Epochs 5 through 9 as illustrated in Figure 4 . Initial assumptions required for this are an early Pliocene age for Core 6 , Section 4 , and the recognition that the low positive inclination value recorded for 
TABLE 2

Summary of Paleomagnetic Data, Site 374

\begin{tabular}{|c|c|c|c|c|c|c|c|c|c|c|}
\hline \multirow[b]{2}{*}{$\begin{array}{l}\text { Sample (In- } \\
\text { terval in } \mathrm{cm} \text { ) }\end{array}$} & \multirow{2}{*}{$\begin{array}{c}\text { Depth } \\
\text { in hole } \\
\text { (m) }\end{array}$} & \multicolumn{4}{|c|}{ N R M } & \multicolumn{5}{|c|}{ After AF Demagnetization } \\
\hline & & $\mathrm{DEC}$ & INC & CSD & $\begin{array}{c}\text { INT } \pm \text { SD } \\
(\mu \mathrm{G})\end{array}$ & $\begin{array}{c}\text { Field } \\
\text { (oe) }\end{array}$ & DEC & INC & $\operatorname{CSD}^{\mathrm{a}}$ & $\begin{array}{l}\text { INT } \\
(\mu \mathrm{G})\end{array}$ \\
\hline $2-1,84-86$ & 157.85 & 235.1 & +57.3 & 0.7 & $55.48 \pm 0.23$ & 50 & 239.8 & +55.3 & - & 41.93 \\
\hline $2-2,123-125$ & 159.74 & 182.2 & +68.2 & 1.3 & $13.00 \pm 0.02$ & 50 & 171.9 & +67.5 & - & 11.78 \\
\hline $2-3,118-120$ & 161.19 & 149.4 & +53.0 & 0.7 & $33.26 \pm 0.22$ & 50 & 158.7 & +67.1 & - & 19.19 \\
\hline $3-1,112-114$ & 209.12 & 242.2 & +65.2 & 1.1 & $2.33 \pm 0.13$ & 50 & 244.7 & +59.8 & - & 1.57 \\
\hline $4-1,140-142$ & 252.91 & 210.9 & +59.1 & 0.7 & $12.01 \pm 0.08$ & 50 & 212.4 & +61.2 & - & 10.30 \\
\hline $4-2,39-41$ & 253.40 & 213.8 & +67.6 & 0.5 & $27.59 \pm 0.23$ & 50 & 222.9 & +67.5 & - & 23.49 \\
\hline $4-3,21-23$ & 254.72 & 281.3 & -57.4 & 1.0 & $6.77 \pm 0.15$ & 300 & 118.8 & +42.5 & - & 0.61 \\
\hline $4-3,32-34$ & 254.83 & 248.5 & +50.2 & 0.9 & $9.42 \pm 0.03$ & 300 & 259.6 & +43.3 & (1.1) & 3.15 \\
\hline $4-4,76-78$ & 256.77 & 200.2 & +75.2 & 1.0 & $12.36 \pm 0.05$ & 300 & 216.0 & +56.7 & (1.9) & 4.34 \\
\hline $4-4,101-103$ & 257.02 & 309.7 & +47.1 & 0.5 & $17.56 \pm 0.07$ & 50 & 312.2 & +48.3 & - & 14.58 \\
\hline $5-2,12-14$ & 298.63 & 278.4 & -55.0 & 3.5 & $1.32 \pm 0.05$ & 50 & 236.4 & -66.0 & 2.1 & 1.43 \\
\hline $5-2,57-59$ & 299.08 & 281.9 & -6.5 & 3.7 & $1.54 \pm 0.12$ & 50 & 270.6 & -48.6 & 1.3 & 1.37 \\
\hline $5-3,32-34$ & 300.33 & 330.0 & +42.0 & 2.5 & $3.59 \pm 0.12$ & 50 & 340.4 & +28.5 & 2.0 & 2.30 \\
\hline $5-4,52-54$ & 302.03 & 78.9 & +56.7 & 4.4 & $0.50 \pm 0.04$ & 300 & 109.2 & +27.2 & $(2.2)$ & 0.25 \\
\hline $5-4,62-64$ & 302.13 & 351.2 & -0.1 & 53.4 & $0.06 \pm 0.03$ & 300 & 8.4 & -43.4 & $(7.2)$ & 0.10 \\
\hline $5-5,53-55$ & 303.54 & 5.2 & +7.9 & 0.5 & $9.87 \pm 0.11$ & 50 & 5.3 & +7.8 & - & 8.88 \\
\hline $6-0,7-9$ & 330.10 & 255.4 & +52.9 & 0.6 & $37.89 \pm 0.21$ & 50 & 254.0 & +53.1 & 0.7 & 37.37 \\
\hline $6-1,25-27$ & 330.76 & 63.4 & -0.2 & 5.1 & $3.11 \pm 0.06$ & 250 & 40.3 & +5.6 & $(4.2)$ & 2.80 \\
\hline $6-1,35-37$ & 330.86 & 81.5 & +38.4 & 0.8 & $26.39 \pm 0.14$ & 300 & 86.3 & +5.5 & $(0.7)$ & 12.88 \\
\hline $6-2,88-90$ & 332.89 & 21.0 & +46.2 & 0.4 & $21.75 \pm 0.31$ & 50 & 27.1 & +46.8 & - & 19.14 \\
\hline $6-3,14-16$ & 333.65 & 328.5 & +47.8 & 2.1 & $0.94 \pm 0.04$ & 50 & 329.7 & +44.7 & 2.0 & 0.89 \\
\hline $6-4,38-40$ & 335.39 & 301.3 & +45.3 & 0.2 & $10.06 \pm 0.01$ & 50 & 282.9 & +43.7 & - & 6.43 \\
\hline $6-5,43-45$ & 336.94 & 0.2 & +9.0 & 0.8 & $17.00 \pm 0.20$ & 50 & 10.6 & +12.6 & - & 5.89 \\
\hline $6-6,103-105$ & 339.04 & 326.3 & +61.2 & 1.1 & $17.77 \pm 0.06$ & 50 & 303.3 & +68.7 & - & 11.59 \\
\hline $7-1,69-71$ & 340.70 & 174.6 & +46.0 & 0.6 & $11.56 \pm 0.05$ & 50 & 169.4 & +46.0 & 0.9 & 11.23 \\
\hline $7-2,56-58$ & 342.07 & 73.9 & +72.6 & 1.0 & $26.27 \pm 0.23$ & 50 & 72.6 & +72.2 & - & 25.73 \\
\hline $7-4,55-57$ & 345.06 & 213.0 & +76.0 & 0.9 & $13.19 \pm 0.08$ & 50 & 230.1 & +76.9 & 1.1 & 11.68 \\
\hline $7-5,35-37$ & 346.36 & 93.4 & +76.3 & 0.8 & $10.22 \pm 0.09$ & 50 & 99.1 & +74.7 & 0.7 & 9.27 \\
\hline $7-6,97-99$ & 348.48 & 238.4 & +52.0 & 0.9 & $13.50 \pm 0.12$ & 50 & 234.5 & +52.8 & 0.8 & 13.10 \\
\hline $8-2,19-21$ & 351.20 & 355.0 & +71.7 & 1.5 & $5.80 \pm 0.09$ & 50 & 342.9 & +64.2 & - & 5.51 \\
\hline $8-3,12-14$ & 352.63 & 13.1 & +62.4 & 0.1 & $8.71 \pm 0.07$ & 50 & 35.6 & +69.6 & - & 6.31 \\
\hline $9-1,5-7$ & 359.06 & 70.8 & +65.5 & 1.6 & $7.88 \pm 0.07$ & 50 & 47.2 & +66.0 & 3.0 & 6.95 \\
\hline $9-2,19-21$ & 360.70 & 319.7 & +37.5 & 1.7 & $2.79 \pm 0.05$ & 50 & 303.9 & +43.3 & - & 1.81 \\
\hline $9-3,49-51$ & 362.50 & 15.6 & +64.0 & 1.8 & $3.33 \pm 0.03$ & 50 & 299.0 & +66.7 & 2.9 & 1.70 \\
\hline $12-1,86-88$ & 382.37 & 276.9 & +2.2 & 3.7 & $0.23 \pm 0.03$ & 250 & 352.3 & -11.3 & $(6.0)$ & 0.03 \\
\hline $12-1,103-105$ & 382.54 & 279.4 & +23.3 & 30.4 & $0.17 \pm 0.08$ & 50 & 259.0 & -17.3 & 15.4 & 0.08 \\
\hline $12-2,30.5-33.0$ & 383.32 & 252.2 & +51.4 & 5.0 & $0.18 \pm 0.01$ & 50 & 260.0 & +42.0 & 3.2 & 0.26 \\
\hline $12-2,33.5-35.5$ & 383.34 & 228.8 & +18.4 & 3.6 & $0.28 \pm 0.03$ & 50 & 243.7 & +17.9 & 6.8 & 0.30 \\
\hline $12-2,36-38.5$ & 383.37 & 140.4 & -9.1 & 6.5 & $0.24 \pm 0.02$ & 50 & 133.7 & -30.9 & 3.9 & 0.30 \\
\hline $12-2,44-46$ & 383.45 & 135.8 & +53.4 & 0.5 & $14.53 \pm 0.11$ & 300 & 140.8 & +25.1 & $(0.5)$ & 2.53 \\
\hline $12-2,103-105$ & 384.05 & 279.4 & +23.3 & 30.4 & $0.17 \pm 0.08$ & 150 & 184.5 & +39.3 & (15.4) & 0.05 \\
\hline $13-1,91-93$ & 388.42 & 257.2 & +83.4 & 14.2 & $15.72 \pm 0.12$ & 50 & 0.2 & +76.7 & 0.6 & 12.71 \\
\hline $13-2,39-41$ & 389.40 & 133.1 & +45.6 & 0.9 & $2.31 \pm 0.03$ & 300 & 124.8 & +52.0 & 1.3 & 2.11 \\
\hline $13-3,13-15$ & 390.64 & 259.5 & +6.7 & 2.0 & $0.67 \pm 0.07$ & 150 & 262.1 & -45.5 & 2.8 & 0.38 \\
\hline $13-3,22-24$ & 390.71 & 302.6 & +25.3 & 1.9 & $0.94 \pm 0.12$ & 250 & 173.6 & -57.0 & $(3.0)$ & 0.31 \\
\hline $13-3,39-41$ & 390.88 & 212.2 & +21.7 & 4.7 & $0.42 \pm 0.17$ & 25 & 214.2 & +23.7 & - & 0.21 \\
\hline $13-3,62-64$ & 391.13 & 218.1 & +73.9 & 0.9 & $1.18 \pm 0.05$ & 50 & 184.0 & +69.5 & 1.6 & 1.26 \\
\hline $13-3,80-82$ & 391.31 & 204.3 & +23.5 & 1.6 & $0.72 \pm 0.07$ & 50 & 194.7 & +8.2 & 2.2 & 0.62 \\
\hline $13-3,119-121$ & 391.70 & 265.2 & +63.2 & 6.0 & $0.36 \pm 0.05$ & 50 & 312.1 & +59.0 & 5.9 & 0.32 \\
\hline $13-3,140-142$ & 391.91 & 301.3 & +26.1 & 2.9 & $0.40 \pm 0.05$ & 50 & 304.6 & +23.9 & 4.4 & 0.41 \\
\hline
\end{tabular}

${ }^{\mathrm{a}} \mathrm{CSD}$ based on 50 oe value.

Sample 7-2, 27-29 $\mathrm{cm}$, may signify a polarity reversal. Support for such an interpretation is provided by its demagnetization behavior as it had not reached a terminal value. An average sedimentation rate of 13 $\mathrm{m} / \mathrm{m}$.y. is calculated from this paleomagnetic correlation. The stratigraphic implications of such a correlation is the necessary dating of the evaporites, which occur 30 meters below the lowermost paleomagnetic sample, at pre-9 m.y. that is within the Tortonian stage.

It should be stressed that the quality of the paleomagnetic data is such that the correlation is equivocal.
An alternative interpretation would necessitate recognizing the existence of many more reversed events within Epochs 5 and possibly 6 than are presently accepted. It remains to be seen whether such short duration polarities can be sought in other comparable studies where high sedimentation rates prevail. Reference to the thinner post-evaporitic sequences studied at Sites 372 and 374, particularly at the latter, appear to support a suggestion that short reversed polarity events characterized this interval within the Messinian stage. 
TABLE 3

Summary of Paleomagnetic Data, Site 376

\begin{tabular}{|c|c|c|c|c|c|c|c|c|c|c|}
\hline \multirow[b]{2}{*}{$\begin{array}{l}\text { Sample (In- } \\
\text { terval in cm) }\end{array}$} & \multirow{2}{*}{$\begin{array}{l}\text { Depth } \\
\text { in hole } \\
\text { (m) }\end{array}$} & \multicolumn{4}{|c|}{ N R M } & \multicolumn{5}{|c|}{ After AF Demagnetization } \\
\hline & & DEC & INC & CSD & $\begin{array}{c}\mathrm{INT} \pm \mathrm{SD} \\
(\mu \mathrm{G})\end{array}$ & $\begin{array}{c}\text { Field } \\
(\mathrm{oe})\end{array}$ & DEC & INC & $\operatorname{CSD}^{\mathrm{a}}$ & $\begin{array}{l}\text { INT } \\
(\mu \mathrm{G}) \\
\end{array}$ \\
\hline $6-4,47-49$ & 50.48 & 328.6 & +46.5 & 8.1 & $0.19 \pm 0.03$ & 250 & 352.3 & -44.0 & $(11.3)$ & 0.05 \\
\hline $6-4,71-73$ & 50.72 & 66.8 & -19.0 & 13.0 & $0.10 \pm 0.03$ & 100 & 325.3 & -84.6 & (11.3) & 0.04 \\
\hline $6-4,75-77$ & 50.76 & 20.9 & +6.2 & 24.6 & 0.03 & 50 & 63.8 & -55.9 & 21.5 & 0.03 \\
\hline $7-1,72-74$ & 55.73 & 153.8 & +23.8 & 0.5 & $27.36 \pm 0.28$ & 100 & 155.0 & +39.6 & $(0.7)$ & 24.11 \\
\hline $7-1,136-138$ & 56.37 & 180.7 & +52.9 & 2.1 & $18.78 \pm 0.45$ & 300 & 166.4 & +48.3 & $(0.9)$ & 7.68 \\
\hline $7-2,27-29$ & 56.78 & 273.5 & +44.5 & 2.1 & $2.52 \pm 0.21$ & 300 & 343.2 & +7.6 & $(2.6)$ & 0.36 \\
\hline $8-2,41-43$ & 66.42 & 351.5 & -9.7 & 0.1 & $24.65 \pm 0.11$ & 300 & 355.1 & -1.6 & $(0.8)$ & 8.18 \\
\hline $8-2,134-136$ & 67.35 & 257.4 & +31.5 & 1.1 & $50.02 \pm 1.24$ & 300 & 247.8 & +34.6 & (2.9) & 13.63 \\
\hline $8-3,32-34$ & 67.83 & 57.9 & +9.5 & 1.5 & $39.21 \pm 0.87$ & 300 & 48.8 & -13.3 & (2.3) & 24.23 \\
\hline $9-1,53-55$ & 74.54 & 335.2 & -26.7 & 1.1 & $64.42 \pm 0.71$ & 300 & 33.4 & -32.0 & (2.4) & 11.49 \\
\hline $9-2,29-31$ & 75.80 & 155.5 & +49.1 & 1.4 & $3.30 \pm 0.01$ & 300 & 90.9 & +48.9 & (1.4) & 0.59 \\
\hline $9-2,144-146$ & 76.95 & 296.0 & +49.1 & 4.6 & $0.24 \pm 0.05$ & 50 & 341.1 & -14.6 & 7.6 & 0.09 \\
\hline $9-3,94-96$ & 77.95 & 299.9 & +46.7 & 1.4 & $4.68 \pm 0.21$ & 250 & 276.7 & -25.4 & $(1.6)$ & 0.69 \\
\hline $9-3,113-115$ & 78.14 & 327.9 & +80.8 & 1.3 & $11.66 \pm 0.17$ & 150 & 191.6 & -58.7 & $(2.5)$ & 0.67 \\
\hline $9-4,49-51$ & 79.00 & 220.0 & +58.0 & 1.3 & $7.09 \pm 0.11$ & 300 & 138.9 & +28.8 & $(0.4)$ & 0.21 \\
\hline $9-4,89-91$ & 79.40 & 283.9 & +36.2 & 2.3 & $8.99 \pm 0.17$ & 300 & 264.0 & +32.5 & $(0.8)$ & 1.42 \\
\hline $10-1,61-63$ & 84.12 & 209.0 & +23.9 & 3.3 & $1.45 \pm 0.15$ & 250 & 209.7 & -22.6 & (2.4) & 0.81 \\
\hline $10-2,25-27$ & 85.26 & 273.8 & +67.9 & 2.7 & $2.93 \pm 0.08$ & 300 & 10.6 & +9.7 & $(2.0)$ & 0.56 \\
\hline $10-2,100-102$ & 86.01 & 86.9 & +21.3 & 2.9 & $0.71 \pm 0.01$ & 150 & 88.1 & -9.5 & $(0.7)$ & 0.44 \\
\hline $10-3,49-51$ & 87.00 & 227.4 & +28.7 & 1.4 & $2.93 \pm 0.04$ & 100 & 322.5 & -52.1 & (1.3) & 0.57 \\
\hline $10-3,130-132$ & 87.81 & 162.3 & +17.5 & 0.5 & $14.70 \pm 0.15$ & 300 & 146.3 & -5.7 & $(0.3)$ & 6.95 \\
\hline $11-2,15-17$ & 94.66 & 135.2 & +16.4 & 1.2 & $3.26 \pm 0.09$ & 300 & 132.8 & -36.9 & $(1.2)$ & 1.39 \\
\hline $11-2,92-43$ & 95.43 & 27.0 & +9.8 & 0.3 & $12.82 \pm 0.04$ & 300 & 28.8 & -17.5 & $(0.8)$ & 4.22 \\
\hline $11-3,11-13$ & 96.12 & 81.6 & -6.8 & 11.9 & $0.36 \pm 0.01$ & 250 & 128.4 & -45.6 & (2.0) & 0.10 \\
\hline $11-3,82-84$ & 96.83 & 316.6 & -2.5 & 3.6 & $0.35 \pm 0.01$ & 300 & 342.7 & -26.7 & $(4.5)$ & 0.10 \\
\hline $11-3,144-146$ & 97.45 & 73.2 & -2.6 & 5.2 & $0.14 \pm 0.002$ & 200 & 89.4 & -31.4 & $(4.9)$ & 0.07 \\
\hline $12-1,37-39$ & 102.88 & 348.7 & +29.7 & 1.2 & $17.13 \pm 0.09$ & 300 & 348.5 & +29.8 & $(0.3)$ & 10.77 \\
\hline $12-1,124-126$ & 103.75 & 312.4 & +15.1 & 5.6 & $0.35 \pm 0.01$ & 300 & 320.8 & -32.6 & $(5.4)$ & 0.08 \\
\hline $12-2,64-66$ & 104.65 & 0.6 & -13.6 & 11.3 & $0.10 \pm 0.01$ & 50 & 37.1 & -19.1 & 23.8 & 0.09 \\
\hline $12-3,80-82$ & 106.31 & 215.0 & +54.5 & 1.1 & $1.95 \pm 0.05$ & 150 & 99.1 & -68.1 & (7.3) & 0.31 \\
\hline $12-4,12-14$ & 107.13 & 1.7 & -15.9 & 7.1 & $0.29 \pm 0.09$ & 150 & 7.8 & -37.5 & $(6.1)$ & 0.06 \\
\hline $12-4,132-134$ & 108.33 & 230.8 & +11.8 & 2.3 & $10.57 \pm 0.18$ & 300 & 230.3 & +6.9 & $(3.0)$ & 5.09 \\
\hline $12-5,56-58$ & 109.07 & 272.7 & +64.6 & 1.7 & $5.72 \pm 0.15$ & 100 & 9.7 & -24.5 & (13.3) & 0.47 \\
\hline $12-5,106-108$ & 109.57 & 127.8 & +59.7 & 0.4 & $4.49 \pm 0.02$ & 300 & 121.1 & -5.1 & $(0.5)$ & 0.39 \\
\hline $13-2,49-51$ & 114.00 & 138.0 & +80.9 & 0.7 & $6.51 \pm 0.04$ & 300 & 93.3 & +54.4 & $(1.5)$ & 0.68 \\
\hline $13-2,146-148$ & 114.97 & 246.9 & +54.2 & 0.7 & $11.29 \pm 0.06$ & 300 & 148.6 & -67.2 & $(0.5)$ & 0.52 \\
\hline $13-4,55-57$ & 117.06 & 125.7 & +83.7 & 14.8 & $0.44 \pm 0.03$ & 150 & 52.2 & -25.9 & $(5.3)$ & 0.07 \\
\hline
\end{tabular}

${ }^{\mathrm{a}} \mathrm{CSD}$ based on 50 oe value.

\section{CONCLUSIONS}

Thorough and careful demagnetization has revealed a sequence of polarity changes from the Mediterranean Sea Sites 372, 374, and 376 which provide some important new data pertinent to the chronology of the post-evaporitic sediments. By using paleontological constraints, a tentative paleomagnetic stratigraphy has been recognized at these sites which can be assigned in part to the established time scale. The validity of this assignment awaits further more detailed studies in some of the critical intervals identified in this preliminary investigation.

\section{ACKNOWLEDGMENTS}

We are grateful to Mrs. P. Copland and Mr. D. Spanner for their assistance with sample preparation and measurement.

We thank Dr. D. H. Tarling for reviewing the manuscript.

\section{REFERENCES}

Cita, M.B., 1975. The Miocene/Pliocene boundary: History and definition: In Late Neogene Epoch boundaries, p. 1-30.

Fisher, R.A., 1953. Dispersion on a sphere: Proc. Roy. Soc. Lond. A217, p. 295-305.

Hailwood, E.A., in press. A preliminary paleomagnetic stratigraphy for lower Eocene sediments at Site 366 (Sierra Leone Rise) and Miocene and Oligocene sediments at Site 368 (Cape Verde Rise), N.W. African Continental Margin. In Lancelot, Y., Seibold, E., et al., Initial Reports of the Deep Sea Drilling Project, Volume 41: Washington (U.S. Government Printing Office).

Hamilton, N., 1974. Explanatory notes-Preliminary paleomagnetic measurements. In Whitmarsh, R.B., Weser, O.E., Ross, D.A., et al., Initial Reports of the Deep Sea Drilling Project, Volume 23: Washington (U.S. Government Printing Office), p. 30.

Molyneux, L., 1971. A complete results magnetometer for measuring the remanent magnetization of rocks: Geophys. J. Roy. Astron. Soc., v. 24, p. 429-433. 


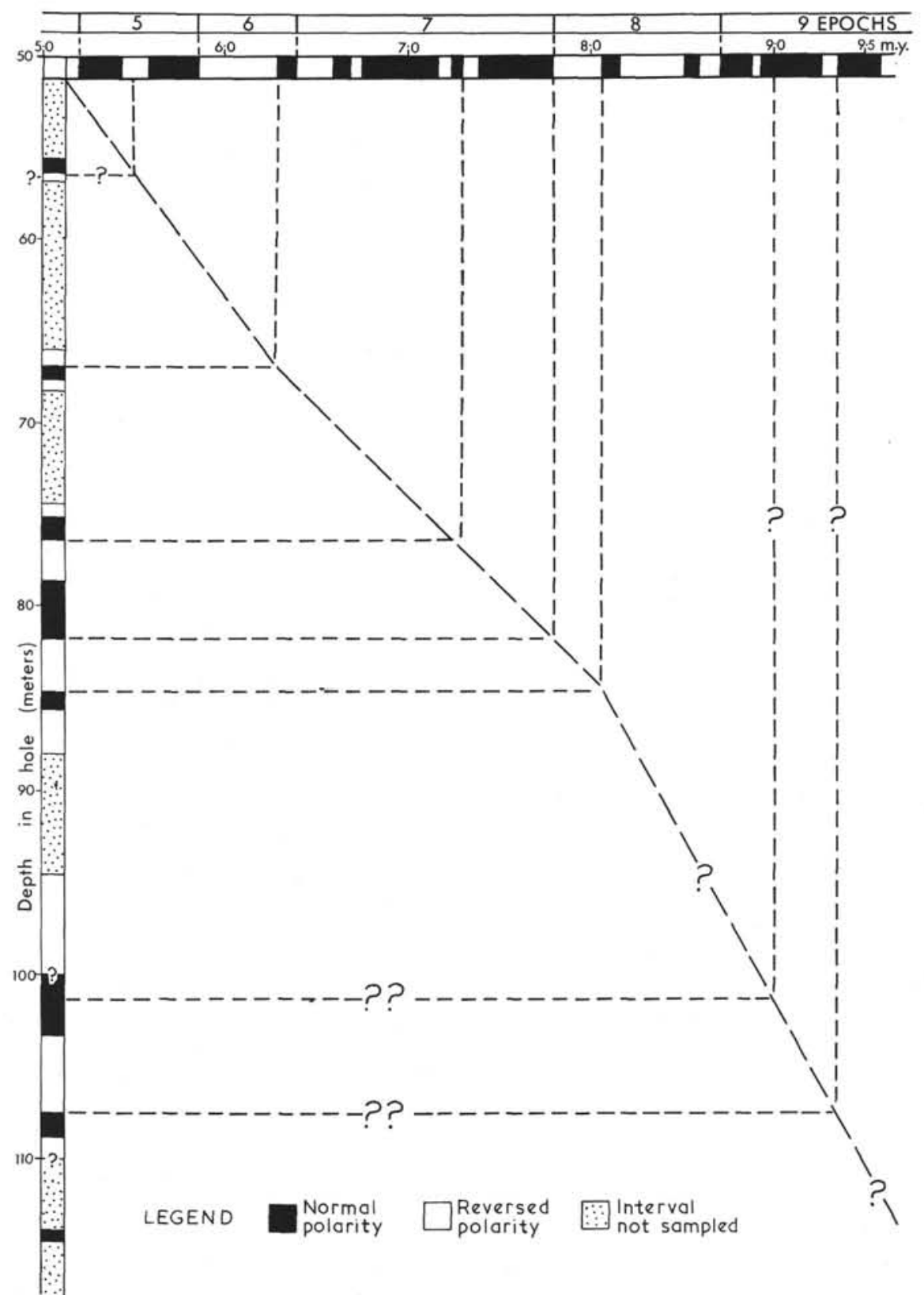

Figure 4. Possible correlation with the established geomagnetic polarity time scale for post-evaporitic (U. Miocene) sediments at Site 376 from which sedimentation rates can be inferred.

Ryan, W.B.F., 1973. Paleomagnetic stratigraphy. In Ryan, W.B.F., Hsü, K.J., et al., Initial Reports of the Deep Sea Drilling Project, Volume 13: Washington (U.S. Government Printing Office), P. 1380-1387.

Ryan, W.B.F., Cita, M.B., Dreyfus Rawson, M., Burckle, L.H., and Saito, T., 1974. A paleomagnetic assignment of
Neogene stage boundaries and the development of isochronous datum planes between the Mediterranean, the Pacific and Indian oceans in order to investigate the response of the world ocean to the Mediterranean 'salinity crisis': Riv. Ital. Paleontol., v. 80, p. 631-688.

Tarling, D.H. and Mitchell, J.G., 1976. Revised Cenozoic polarity time scale: Geology, v. 4, p. 133-136. 